African Journal of Educational Studies in Mathematics and Sciences Vol. 15, 2019

\title{
Ghanaian public and private junior high school mathematics classroom learning environment: A look at students' attitudes
}

\author{
R. Asomah Kyere ${ }^{1}$, H. Dennis ${ }^{2}$, M. N. Alhassan ${ }^{3}$, and J. K. Aseidu ${ }^{4}$
}

\begin{abstract}
The public outcry about students' poor performance in mathematics can be said to have gained currency in recent times, in the dailies in Ghana. The outcry has been fueled by the fact that Ghanaian eight graders have always been among the least performing in international assessments such as TIMSS. Since available literature is replete with the fact that students' attitudes of their mathematics classroom environment influence their attitudes to their classroom activities and hence their mathematics achievement, this study was designed to determine the attitudes of junior high school pupils towards their mathematics classroom learning environment. A total of 350 eighth and ninth graders (i.e., forms two and three junior high school students) from four public and two private randomly selected schools in a metropolitan community in southern Ghana participated in the study. The study adapted the mathematics attitude questionnaire (MAQ) instruments, a questionnaire designed to measure students' attitudes of their classroom environment on four different subscales. The results revealed that, though in general, the attitudes of students were positive, that of the private school students were relatively more positive than their public-school counterparts in each of the subscales. Implications of this are discussed and recommendations for classroom teachers and future research are also presented.
\end{abstract}

Keywords: normality of mathematics, attitude towards mathematics inquiry, adoption of mathematics attitude, enjoyment of mathematics

\section{Introduction}

Mathematics has played a strategic role in the development of humanity and it has always assumed a significant and unique role in many societies throughout history. The awareness and general understanding of the role mathematics has in our daily lives is as essential for women as it is for men if they are to make informed, responsible decisions. There is the need to actively encourage students to develop positive attitudes toward the learning of mathematics. The consequent of which will faciltate the necessary confidence in the students ability to solve mathematical problems and in the continuum enable them to benefit from the vast opportunities in mathematics. If students show negative attitudes toward mathematics, it may result in the students being disadvantaged in

\footnotetext{
${ }^{1}$ Asomah Kyere Richard is a Ph.D. candidate (Mathematics Education) UCC, Ghana. Email: asomahkyererichard@yahoo.com

${ }^{2}$ Hager Dennis and Alhassan Mohammed Nurudeen are Tutors in Department of Mathematic and ICT, Ola College of Education, Ghana;

${ }^{3}$ Aseidu Kofi Joseph is a Tutor, Department of Mathematic and ICT Al-Faruq College of Education, Ghana.
} 
Ghanaian public and private junior high school mathematics classroom learning environment: $A$ look at students' attitudes

R. Asomah Kyere, H. Dennis, M. N. Alhassan and J. K. Aseidu

their ability to study mathematics at higher levels (AAT, 1991). Thus, if negative attitudes toward mathematics is a dominate emotion then this can lead to the loss of the benefits of the knowledge derived from studying mathematics for the students themselves, their communities and the nation as a whole. If students are to function effectively and contribute to the development and progress of a nation, they must understand and be able to use mathematics in both their personal and professional lives. There has never been a greater need to be mathematically literate than in a rapidly expanding society and economy. Those who understand and can do mathematical computations will have significantly enhanced opportunities and options that will open doors to a productive future. For instance, in Ghana, a failure on the mathematics papers at both basic education level (Basic Education Certificate Examinations) as well as secondary school level (Senior Secondary School Certificate Examinations [SSSCE] or the West African Senior Secondary School Certificate Examinations [WASSCE]) organized by the West African Examinations Council (WAEC) denies the candidate progression to the next level of his or her education. This explains the importance attached to the study of mathematics in Ghanaian schools. Those who lack mathematical competence will find many doors leading to a productive and successful future closed

Whiles in the recent past, the Basic Education Certificate Examination (BECE) depicted an impressive performance in mathematics by the Junior High School pupils (Chief Examiners Report, BECE 2010). A large scale international comparative study, such as Trends in International Mathematics and Science Study (TIMSS) by the International Association for the Evaluation of Educational Achievement (IEA) reports that "Ghana's JHS2 students' performance in mathematics and science, though improved significantly since TIMSS 2003, remains among the lowest in Africa and the world."(TIMSS'2007) Again, Anamuah-Mensah \& Mereku reported the abysmal performance of Ghanaian basic school pupils in mathematics both locally and internationally (Anamuah-Mensah \& Mereku, 2005; WAEC, 2006),

It is aginst this background that, the pupils' attitudes would be valuable and necessary information for the understanding and interpreting Ghanaians mathematics classroom practice most especially, in the Cape Coast Metropolis. However, there have thus far been few attempts to investigate how pupils at the basic level of Ghanaian educational system, who experience mathematics classroom as both insiders and builders, behave towards their mathematics classroom environments. Although some researchers have started to investigate elementary school mathematics classroom learning environments in Ghana.(e.g. Wilmot, 2001; Duedu, 2008 ), The net effect of these studies are that whether the attitudinal patterns of these students towards the learning environment is as either positive or negative may influence the participants in the learning environment, few have explored the attitudinal patterns of Ghanaian junior high school pupils towards their mathematics learning environments and in view of this, the present study explores how junior high school pupils in Ghanaian educational system most especially in the Cape Coast Metropolis which is perceived to be the Centre of the Ghanaian educational system taking into consideration its strategic location in the country, the highly competitive senior high schools and its related highly equipped educational facilities, exhibit their attitudinal traits towards their mathematics classroom learning environments.

Borasi (1990) reported that the conceptions, attitudes and expectations of students regarding mathematics and teaching of mathematics are very significant factors underlying their school experience and subsequent achievement in the subject. Other studies (e.g., Fraser \& Kahle 2007; 
Goh \& Fraser, 1998), have found that mathematics classroom learning environments strongly influence students' attitudes towards mathematics and mathematics learning. Inferring hypotheticodeductively, as far as the underachievement of mathematics in Ghana is concerned, a research that is carried out in response to the perceived elements that militate against the smooth consolidation of the gains made in the teaching and learning of mathematics cannot be over emphasized.

This study seeks to find out junior high school pupils' attitude towards mathematics. It also sought to find out whether there was any variation in attitude by pupils from public and private schools towards their mathematics classroom learning environment. The study also focused on junior high school pupils' attitude towards mathematics to determine whether they had a favourble or unfavourable attitude towards the subject. There is the need therefore to measure the attitudes of students towards mathematics in the classroom learning environment in Ghana since the teaching and learning of mathematics is compulsory for all junior high school pupils, and therefore pupils who dislike the subject "have to grind at it with the rest" (Clements, 1979). The following research questions were formulated to guide the study:

1. What are the junior high school pupils' general attitudes towards their mathematics classroom learning environment?

2. What are the private junior high school pupils' attitude towards their mathematics classroom learning environment?

3. What are the public junior high school pupils' attitude towards their mathematics classroom learning environment?

4. What are the junior high school pupils' attitude towards mathematics based upon school-type?

\section{Methodology}

\section{Research design, population and sample}

The cross-sectional survey was used in this study. A survey of junior high school pupils' attitude towards mathematics was conducted from which inferences were made about the pupils' attitude towards mathematics.

This design was considered appropriate since the study sought to describe the junior high school pupils attitude towards mathematics without manipulating the environment within which they found themselves. Moreover, Fraenkel and Wallen (2000) had argued that cross-sectional survey has the potential of providing a lot of useful information about the subjects of the study for instance the public and private Junior high school pupils' attitude towards mathematics.

Mitchell and Jolley (2004) also noted that the cross-sectional survey is more economical because it makes it possible for many subjects to be studied at the same time. This was the case in this study since as many as 350 junior high school pupils were sampled and studied at the same time as well as the economy of time to both the researcher and the schools involved in this study since each of the private and public schools involved in this study was visited only once during the data collection stage.

Although this design was efficient, weaknesses identified in using this design were; ensuring that questions were clear and devoid of any ambiguities, getting respondents to answer questions thoughtfully and honestly, (Fraenkel \&Wallen, 2000; Cohen, et al, 2000). This was because in 
Ghanaian public and private junior high school mathematics classroom learning environment: $A$ look at students' attitudes

R. Asomah Kyere, H. Dennis, M. N. Alhassan and J. K. Aseidu

answering the items on the instrument that is, the mathematics attitude questionnaire (MAQ), the researcher had to give further explanation on some of the items and also from time to time advice the respondents to take their time to read the statements before responding to them.

\section{Population}

The target population of this study was all junior high school pupils since the teaching and learning of mathematics is compulsory at the basic level of education in which the junior high school pupils in the Cape Coast Metropolitan Area was no exception. There were eighty-five junior high schools comprising twenty-six private and fifty-nine public schools, in the Cape Coast Metropolitan Area during the 2013/2014 academic year. Out of this number of schools, six of them served as the sample for the study comprising four public schools with the remaining two schools being private.

Sample and sampling technique

In all, 350 junior high school pupils during the 2013/14 academic year formed the sample for the study. There were 141(40.3\%) pupils from private schools and 209(59.7\%) from public schools. The age distribution of the respondents ranged from 10 years to 21 years with an average age of 15.08 years and a standard deviation of 1.51 .

A multi-stage sampling technique was used to obtain the schools that participated in the study. The six schools were first selected using simple random sampling technique from the eighty-five junior high schools in the Cape Coast Metropolitan Area, Specifically, two private and four public junior high schools (table of random numbers). From these six schools, twelve intact junior high schools' classes were selected using convenience sampling method. These junior high schools' classes were selected because they happened to be the classes that were having mathematics lessons at the time of the data collection. Two classes each were selected from the public and private schools.

Table 1: $\quad$ Background Characteristics of the Participants

\begin{tabular}{lccc}
\hline Form & Pupils in Private schools & Pupils in Public schools & Total \\
\hline JHS 2 & 60 & 89 & 149 \\
JHS 3 & 81 & 120 & 201 \\
Total & 141 & 209 & 350 \\
\hline
\end{tabular}

\section{Instrument}

Data for the study was collected using the five-point Likert scale type questionnaire measuring the junior high school pupils' attitude towards mathematics. The instrument, the Mathematics Attitude Questionnaire (MAQ) was developed to measure junior high school pupils' attitude towards mathematics using the Test of Mathematics-Related-Attitude (TOMRA) as used in Ntow (2009) and developed by Taylor (2004) as a guide. The instrument was further modified to suit the linguistic abilities of the pupils and all forms of ambiguities since this was at the lower level (Junior High school). The TOMRA measures pupils' attitude in four areas namely:

1. Normality of mathematics

2. Attitude towards mathematics Inquiry 


\section{Adoption of mathematics Attitude}

4. Enjoyment of mathematics Lesson

A five-point Likert-scale was used in developing the mathematics attitude questionnaire (MAQ) and the items on it were developed based upon two subscales namely Attitude towards mathematics Inquiry and Enjoyment of Mathematics Lessons of the test of mathematics related activity (TOMRA). These two subscales were used, as they were perceived to be acquired in the learning environment. There was 12 items in all on the mathematics attitude questionnaire (MAQ) with responses ranging from Strongly Disagree (SD), Disagree (D), Undecided (U), Agree(A), Strongly Agree(SA), These responses were assigned the following values; Strongly Disagree-1, Disagree-2, Undecided-3, Agree-4 and Strongly Agree-5 for positively worded statements with the scoring being reversed for negatively worded statements to reflect the degree to which the respondents possessed that attitudinal trait being measured in that continuum. A detailed description of test of mathematics related activity (TOMRA) as developed by Taylor (2004) and adapted in this study as presented in Table 2.

Table 2 Description and sample item for each Dimension of the mathematic Attitude Questionnaire (MAQ)

\begin{tabular}{|c|c|c|}
\hline Dimension & Description & Sample Item \\
\hline $\begin{array}{l}\text { Normality of } \\
\text { Mathematics }\end{array}$ & $\begin{array}{l}\text { Extent to which pupils see } \\
\text { mathematics as normal }\end{array}$ & $\begin{array}{l}\text { It is better to search for information } \\
\text { concerning mathematics on my own than } \\
\text { resort to my mathematics class teacher }\end{array}$ \\
\hline $\begin{array}{l}\text { Attitude towards } \\
\text { mathematics } \\
\text { Inquiry }\end{array}$ & $\begin{array}{l}\text { Extent to which pupils are } \\
\text { prepared to go extra mile to find } \\
\text { solution to mathematics problem }\end{array}$ & $\begin{array}{l}\text { I would rather agree with other mathematics } \\
\text { pupils in class as to the solution to a } \\
\text { problem than investigate it myself }\end{array}$ \\
\hline $\begin{array}{l}\text { Adoption of } \\
\text { mathematics } \\
\text { attitude }\end{array}$ & $\begin{array}{l}\text { Extent to which pupils are ready } \\
\text { to accept mathematics without } \\
\text { any reservation. }\end{array}$ & $\begin{array}{l}\text { Mathematics is one of the most interesting } \\
\text { school subjects. }\end{array}$ \\
\hline $\begin{array}{l}\text { Enjoyment of } \\
\text { mathematics } \\
\text { lessons }\end{array}$ & $\begin{array}{l}\text { Extent to which pupils' } \\
\text { work/learn mathematics with } \\
\text { ease, excitement and enthusiasm. }\end{array}$ & I really expect more mathematics lessons. \\
\hline
\end{tabular}

\section{Validity}

The instrument, mathematics attitude questionnaire MAQ) was thoroughly discussed with WAEC examiners and supervisors and the possible outcomes agreed on as far as the face validity of the instruments was concerned, since all of them are well versed in a similarly related research involving classroom learning environment. Again, two colleagues who teach at the senior high school and who have taught at the junior high school level before and three junior high school teachers were also given the instruments to assess the items. Through these processes the appropriateness of the language used was checked in order that the pupils understood the items on it. Again, certain wordings which were perceived to be ambiguous were also modified as well as checking the various items to ensure that the items really measured what they were intended to measure. 
Ghanaian public and private junior high school mathematics classroom learning environment: $A$ look at students' attitudes

R. Asomah Kyere, H. Dennis, M. N. Alhassan and J. K. Aseidu

\section{Pilot Testing}

The instrument, mathematics attitude questionnaire (MAQ) was pilot- tested in a school in the Komenda-Edina-Eguafo-Abirem (KEEA) district in the Central Region of Ghana with similar characteristics as those that were used for the actual study in the Cape Coast Metropolitan Area since the teaching and learning of mathematics is compulsory at the basic level of the Ghanaian educational system. Fifty-eight junior high school pupils from four intact classes who were having mathematics lessons at the time of conducting the pilot-test were used. In all, there were 30 males and 28 females from both public and private schools who took part in the pilot- test with each pupil responding to the instrument.

The instrument was retrieved from the junior high school respondents immediately after completion and the data obtained analysed by computing their reliabilities and inter-item correlations. Based upon the inter-item correlation, some of the items were modified.

\section{Reliability}

The reliabilities of the instrument were estimated using the Cronbach Alpha to determine whether each item under the various subscales was related to each other after the pilot- testing exercise and again after the actual data collection for the studies. During pilot- testing exercise, the reliability estimates obtained using the Cronbach Alpha ranged from 0.69 to 0.75 on the mathematics attitude questionnaire (MAQ). During the actual data collection exercise, the reliability estimates obtained on the mathematics attitude questionnaire (MAQ) instrument, the alpha reliability estimate obtained was 0.79 . These reliability estimates were considered appropriate based upon the threshold of 0.60 suggested by Nunnaly (as cited in Ampiah, 2006) in determining whether a research instrument is reliable or not and revealed that these subscales were reliable.

The instruments were administered by the researcher in the various schools during their mathematics lesson periods so that the respondents will be in their mathematics classroom learning environment to respond accordingly. The pupils were made to respond to the instrument after which it was immediately collected. In all, 350 questionnaires were distributed and all were collected indicating a $100 \%$ return rate.

\section{Data Analysis}

To answer the research question which sought to determine junior high school pupils' attitude towards mathematics based upon school-type. To answer this question, individual item means and frequency distributions of the various items on the mathematics attitude questionnaire (MAQ) instrument were scored for individual pupils after which individual item means and overall subscale means were calculated, first without the school-type and secondly, for each school-type. The responses that were obtained from the data collection process were coded from 1-5 for positively worded items from Strongly Disagree to Strongly Agree in that continuum whiles for negatively worded statements the coding was reversed. The Undecided response, which was coded 3 , served as the average which was used to determine the direction of pupils' responses, that is, whether favourable or unfavourable.

In order to do this, the responses that were obtained from the data collection process were coded from 1-5 for positively worded items from "Never" to "Always" in that continuum. This indicated the relative standing of the individuals on the dimensions on the perception instrument. After obtaining the mean of means, those items which recorded means above the overall scale mean 
were selected and commented on as well as those items whose means fell below the subscale mean for the various school- types. Again, items which were expected to record either higher mean values or lower mean values but turned out otherwise were also commented on.

\section{Results/Findings}

The research question sought to determine junior high school pupils' attitude towards mathematics based on their school-type. The item mean scores and standard deviations of the two school-types provides a meaningful basis for comparing the participants' favourable or unfavourable attitude towards mathematics based on the 12 items on the mathematics attitude questionnaire (MAQ) as far as the presentation and discussion of the trends in Junior High School pupils' attitudes toward mathematics is concerned. The positive attitudinal items were rated as follows; 5-strongly agree, 4 - agree, 3 - undecided, 2 - disagree and 1 - strongly disagree whereas the negative attitudinal items were rated as follows; 5 - strongly disagree, 4 - disagree, 3 - undecided, 2 - agree and 1strongly agree. Thus, a mean of more than three indicates favorable attitude, a mean of less than three indicates unfavorable attitude whereas a mean of three indicates neither favorable nor unfavorable attitudes for each of the individual items as presented in Table 3.

From the results as shown in the table, item one was used to find out whether respondents persevere on a mathematical problem until they have solved it themselves. The pupils from the two-different school-types recorded a mean far exceeding the mean score of 3.70 indicating that, they "Agree" or at best "strongly agree" to have persevered on mathematical problems posed to them in their mathematical classroom learning environment, until such problems have been solved (as shown on Table 3). Moreover, from the distribution of responses, 65(31.2\%) out of 209 public school respondents "strongly agreed" as against 11(5.3\%) who "strongly disagreed" hardly do they persist on any mathematical problems undertaken in class. 64 (45.7) out of the 141 private school respondents were also found to have "strongly agreed" in persevering on mathematical problems in class, on the contrary, $9(6.4 \%)$ of them "strongly disagreed".

Again, a positive dispositional attitude was recorded by the junior high school pupils from both private and public-school pupils towards mathematics as a subject on item 7 . This item sought to elicit from the respondents whether they see mathematics as one of the most interesting school subjects. The mean score above 3.70 was recorded for the two schools. This gives an indication that, the pupils irrespective of their school type were more than "decided" as far as their interest in mathematics is concerned. This is interesting considering the perceived negative tendencies, misconceptions and the difficulty associated with mathematics as expressed by many researchers including Richards as cited in (Eshun, 2000) among others. The distribution of responses indicated that the following percentages of pupils "strongly agreed" that mathematics is one of the most interesting school subjects as measured on item seven: 89(42.6\%) out of 209 public school respondents and $51(36.4 \%)$ out of the 141 respondents from the private school. 
Ghanaian public and private junior high school mathematics classroom learning environment: A look at students' attitudes

R. Asomah Kyere, H. Dennis, M. N. Alhassan and J. K. Aseidu

Table 3 Mean Scores and Standard Deviations of items on the MAQ scale by school-type

\begin{tabular}{|c|c|c|c|c|}
\hline \multirow[b]{3}{*}{ Statement } & \multicolumn{4}{|c|}{ School type } \\
\hline & \multicolumn{2}{|c|}{$\begin{array}{c}\text { Private } \\
(\mathrm{N}=141)\end{array}$} & \multicolumn{2}{|c|}{$\begin{array}{c}\text { Public } \\
(\mathrm{N}=209)\end{array}$} \\
\hline & Mean & S. D & Mean & S. D \\
\hline $\begin{array}{l}\text { a. I would prepare to find out why something is true by } \\
\text { solving a math problem than being told. }\end{array}$ & 4.2 & 1.1 & 3.9 & 1.1 \\
\hline b. Mathematics lessons are not fun. & 2.9 & 1.6 & 2.7 & 1.5 \\
\hline $\begin{array}{l}\text { c. It is better to search for information concerning } \\
\text { mathematics problems on my own than from my } \\
\text { mathematics teacher. }\end{array}$ & 3.3 & 1.4 & 3.5 & 1.4 \\
\hline d. I dislike mathematics lessons & 2.1 & 1.2 & 2.5 & 1.5 \\
\hline e. There should be more mathematics lessons each week. & 4 & 1.3 & 3.9 & 1.1 \\
\hline $\begin{array}{l}\text { f. I would rather agree with other mathematics students in this } \\
\text { class as to the solution to a problem than investigate it } \\
\text { myself. }\end{array}$ & 2.7 & 1.4 & 2.9 & 1.5 \\
\hline g. Mathematics is one of the most interesting school subjects & 3.8 & 1.3 & 4 & 1.2 \\
\hline $\begin{array}{l}\text { h. It's better to ask my math class teacher the answer to a } \\
\text { mathematics problem than to find out by trying a } \\
\text { mathematics problem. }\end{array}$ & 3.2 & 1.4 & 3.4 & 1.4 \\
\hline i. I really enjoy mathematics lesson periods & 3.8 & 1.2 & 3.9 & 1.2 \\
\hline $\begin{array}{l}\text { j. The topics covered in mathematics lessons are not } \\
\text { interesting }\end{array}$ & 2.3 & 1.2 & 2.7 & 1.4 \\
\hline k. I really expect more mathematics lessons & 3.7 & 1.2 & 3.9 & 1.2 \\
\hline $\begin{array}{l}\text { 1. I would enjoy school more of they were no mathematics } \\
\text { lessons }\end{array}$ & 2.4 & 1.4 & 2.4 & 1.5 \\
\hline
\end{tabular}

The junior high school pupil's quest to expect more mathematics lessons is an ample evidence of their positive attitude developed, towards mathematics as a subject at the basic level of education. The above mean score observation of 3.50 as indicated on the measurement subscale shows that junior high school pupils irrespective of school-type "Agree" in their expectation of learning more mathematics lessons than "Disagree" to have less lessons in mathematics learnt. The distribution of responses from the respondents indicates the following percentage of junior high school pupils "strongly disagreeing" with the expectation of more mathematics lessons in their mathematics classroom learning environment in their respective schools as follows: 12(5.7\%) out of 209 respondents from the public school as against 78(37.3) who "strongly agreed" and also 8(5.7\%) out of the 141 respondents from the private school as against 40(28.8) who "strongly agreed".

The last item of the mathematics attitude questionnaire was used to find out from the respondents whether they would enjoy school more if there were no mathematical lessons. The distribution of responses indicated a very impressive disposition by the junior high school pupils towards mathematics as a subject 32(15.5\%) out of the 209 respondents from the public school and 
$17(12.1 \%)$ out of 141 respondents from private school were all strongly in Agreement with the assertion that they would enjoy school more in the absence of mathematics lessons. However, 88 $(42.5 \%)$ out of the 209 respondents from the public school and 58(41.1\%) out of the 141 respondents from the private school also "strongly disagreed" to enjoying school more, if there were mathematical lessons.

\section{Discussion}

These findings differ from those in previous similar studies conducted in Ghanaian contexts. In Eshun (2000) study; for example, "Richards (as cited in Eshun 2000) posted that the perception of most people that, among all school subjects, mathematics is the most feared subject. He goes further to state that if asked to sum up their view of mathematics at school, many people would describe it in terms of one, if not all, of the three D's - dull, difficult and dislike" cannot be said to have gained currency at the basic level of education especially, at the junior high school since the disposition by the junior high school pupils vis-a -vis their responses on the 12 items on the MAQ, perceive mathematics as completely opposite to the three D's - dull, difficult and dislike espoused, irrespective of their school-type. Given the grade differences identified in the current study, however, the differences between it and Eshun's study might be attributable to the grade differences of the respective participants. Indeed, Duedu (2008) found that JSS students in general had positive attitudes toward mathematics with respect to the four aspects of attitude to mathematics examined, much as was found in the current study. This further suggests that, although the newest mathematics curriculum standard, which has been implemented in Ghana since 2007, promotes student-centered teaching and cooperative learning, teachers in the Cape Coast Metropolis are on course in the implementation of these in their practice at the junior high school level

\section{Conclusion and Recommendation}

Also, the observation that junior high school pupils from both the private and public schools all had a favourable attitude towards mathematics with no significant school-type related differences in attitude being detected gives an indication that attitude towards mathematics is independent of the school-type. Nevertheless, common sense reveals that one is likely to achieve higher in something one enjoys doing, has confidence in learning or finds useful. Thus, a favourable attitude towards various aspects of mathematics is desirable. Attitude towards mathematics may influence the readiness and willingness with which an individual would learn and benefit from mathematics instruction and ultimately improve the perception of the pupils. Hence the need to introduce into mathematics classroom learning environment, readily available mathematics teaching and learning materials (TLMs) so as to sustain the pupils' appetite for mathematics. Again, the pupils "agreed" than were "undecided" to the phenomenon of normality and enjoyment of mathematics hence depicting an impressive favourable dispositional attitude towards mathematics.

Since junior high school pupils had a favourable attitude towards mathematics, irrespective of school-type, mathematics educators should capitalize on this favourable attitude to help pupils appreciate the learning of mathematics through adequate prior preparation and improvisation of some mathematical concepts in order to retain such level of confidence reposed in the subject. 
Ghanaian public and private junior high school mathematics classroom learning environment: $A$ look at students' attitudes

R. Asomah Kyere, H. Dennis, M. N. Alhassan and J. K. Aseidu

\section{References}

Anamuah-Mensah, J., \& Mereku, K. (2005). Ghanaian JSS2 students' abysmal mathematics achievement in TIMSS-2003: a consequence of the basic school mathematics curriculum. Mathematics Connections, 5, 1-13.

Australian Association of Mathematics Teachers (AAT, 1991). National statement on girls and mathematics. GASAT 6 International Conference Report Australia.

Asomah R. K. (2015) Junior High School Pupils' perception of their mathematics classroom environment learning environment and attitude towards mathematics. A Thesis submitted to the Department of Mathematics and Science Education of the Faculty of Education, University of Cape Coast, in Partial Fulfillment of the Requirements for the award of the Degree of Master of Philosophy in mathematics education.

Bruner, J. (1996). The culture of education. Cambridge, MA: Harvard University Press.

Clements (1979) Journal House of Representative Sixty-six...-WordPress.com https:\\ lintvkxan.files.wordpress $|2015| 01 \mid$ ia_clements_1.16.79.pdf

Fraser, B. J. (1998). Classroom environment instruments: Development, validity and applications. Learning Environment Research, 1, 7-33.

Ntow, F. D. (2009) Senior Secondary School Students' perception of their core mathematics classroom environment and attitude towards core mathematics. A Thesis submitted to the Department of Mathematics Science Education of the Faculty of Education, University of Cape Coast, in Partial Fulfillment of the Requirements for the award of the Degree of Master of Philosophy in mathematics education

Borasi, R. (1990). The invisible hand operating on mathematics instruction; Students conceptions and expectations. In T.J. Cooney, (Ed.), Teaching and learning mathematics in the 1990s, (NCTM Yearbook), pp.174-182. Reston: NCTM.

Curriculum Research and Development Division. (2002). Teaching syllabus for mathematics (Junior High School). Accra, Ghana.

Curriculum Research and Development Division. (2007). Teaching syllabus for mathematics (Junior High School). Accra, Ghana.

Duedu, C. B. (2008). Attitude of junior secondary school students in the cape Coast Metropolitan area towards mathematics, mathematical connection.7.1-3

Eshun, B.A. (1999). The pattern of mathematical achievement of secondary school students in Ghana. Journal of Science and Mathematics Education, 2(1), 22-33.

Curriculum Research and Development Division. (2007). Teaching syllabus for mathematics (Senior High School). Accra, Ghana.

Fraenkel, J. R., \&Wallen, N. E. (2000). How to design and evaluate research in education( $4^{\text {th }}$ ed.). USA: McGraw-Hill Company Inc. Fraser, B. J. (1998a). Validity and Use of Classroom Environment Instruments. Journal of Classroom Interactions, 26(2), 5-11. 
Fraser, B. J. (1998b). Science learning environments: Assessment, effects and determinants. In B.J Fraser and K.G Tobin (Eds.), International Handbook of Science Education, pp 527-564. Dordrecht, The Netherlands: Kluwer Academic Publishers.

Fraser, B. J., \& Kahle, J. B. (2007). Classroom, home and peer environment influences on student outcomes in science and mathematics: An analysis of systemic reform data. International Journal of Science Education, 29, pp 1891-1909.

Goh, S. C., \& Fraser, B. J. (1998). Teacher interpersonal behaviour, Classroom Environment and Student Outcomes in Primary Mathematics in Singapore. In B.J Fraser and K.G Tobin (Eds.), International Handbook of Science Education, pp 199-229. Dordrecht, The Netherlands: Kluwer Academic Publishers.

Mitchell, M. L., \&Jolley, J. M. (2004). Research design explained (5th ed.). Wadsworth: Thompson Learning Inc.

Nworgu, B. G. (2006). Educational Research: Basic issues and methodology. Ibadan: Wisdom Publishers Limited.

Taylor, B. J. (2004). The influence of classroom environment on high school students' mathematics anxiety and attitudes. Unpublished PHD thesis submitted to Curtin University of Technology, Australia.

The West African Examinations Council. (2010). Chief examiners' report on the basic education certificate examination. Accra: Wisdom Press.

Trends in International Mathematics \& Science Study. (2007). International student achievement in mathematics. Boston: TIMSS \& Pirls

Wilmot, E. M. (2001). Gender differences in mathematics achievement in primary schools in Ghana. Mathematics Connection, 2, 25-29. 